\title{
Tourist Quarter "Chinese-Baroque" of Dao Way District in Harbin City: experience, problems and perspectives of renovation.
}

\author{
Svetlana Levoshko ${ }^{1, *}$, and Igor Kirichkov \\ ${ }^{1}$ The Research Institute of Architecture and Urban Planning Theory and History affiliate of Central \\ Scientific Research and Desighn Institute of Ministry of Housing and Building in Russia, 105264 7- \\ ya Parkovaya str. 21a, Moscow, Russia \\ ${ }^{2}$ Harbin Institute of Technology. Architectural Design and Research Institute of HIT, China Post \\ Index 150001 Huanghe Road 73, Nangang District, Harbin City, China
}

\begin{abstract}
This article analyzes results of an unique experience of the Dao Wai historic district renovation project in Harbin of the 2010th. It includes an interpretation of the stylistic features of the Dao Wai building. Also, there was made a presumptive conclusion about the origins of the "Chinese Baroque", which is now famous Dao Wai, combining European order architecture and far Eastern decorative tradition. Presumptive conclusion was based on the construction area observing in 2011-2016 and on the Chinese sources. As a result of renovation, there was formed a new public space with high tourism potential. Social value and status of the Dao Wai has significantly grown. The significant cost increase of real estate and provided services is an essential consequence of the gentrification method. There are were noted increased problems of the native people forced to move from the center to the outskirts of the city. Also, this article analyzes the current stage of the second phase design of Dao Wai renovation project and the perspectives for its implementation.
\end{abstract}

\section{Introduction}

Today Dao Wai district (former name Fu Jia Dian) is one of the three largest touristic centers originally from the heritage Harbin city. It became this by his unique development and huge territory renovation project realization in 2010th. [1-3]

Memoirs and other nonscientific literature of early 1920th called Fu Jia Dian as a "Chinese city of the new formation", and on the plans of Harbin after 1917 Fu Jia Dian was called as a «city». However, Chinese researcher Mi Da Wei wrights, that it wasn't separated city, but a district, which submitted to Chinese government, and this is the main specialty, that predetermined special and unique development of $\mathrm{Fu}$ Jia Dian [1]. Being

\footnotetext{
* Corresponding author: s levoshko@mail.ru
} 
independent from administrative system, it was actually the new phenomenon in Chinese urban planning organization, include functional and architectural design meaning.

The researching area is known as the "Chinese Baroque" [4-5]. It has a very limited dissemination in Harbin, no wonder that today the brand of Dao Wai exactly became this style, mainly focused on the Jing Yang Street .

The renovation development concept of Dao Wai district was made in the middle of 2000th. It was preceded by some experience of reconstruction area in the middle of 1990th, now estimated as negative. The big part of the heritage buildings on the North-West of Dao Wai was deconstructed, and on this place were created the new three-floor buildings, which don't satisfy historical environment stylistic requirements and functional tradition.

"The Conservation and Renovation Project of Heritage Dao Wai District" was designed by Harbin Urban Design Institute group in 2007-2011 years. Project realization area estimated near to $20 \%$ of historical territory of Dao Wai. The Hao Min Ju Development Company, director of the company Mr. Wang Liren has been realizing this project for more than three years. This project was observed in professional community and won award as one of the best and capital-intensive project of 2013. The capital investments is more than 8.33 billion dollars, land area -28.5 hectare, building area (with the floors) $500000 \mathrm{~m}^{2}$. [6]

\section{History of Fu Jia Dian - Dao Wai district development}

The situation schemes of Harbin city, founded by Russians, even from 1898 has a little spot of Chinese settlement that is called Fu Jia Dian. The translation of Fu Jia Dian from Chinese language is meaning "the trade house of the Fu's family". Despite of this district has many other trade houses with different family clans, but this district exactly was named by this toponym. Originally it was the place for Chinese workers settlers, who build the railway bridge through the Sungari river (Song Hua Jiang). More than 10000 of Chinese workers lived here on 1898, and then population became more than 25000 on 1903 [1, 7]. As the rule, European cities in Asia were designed like urban systems that not include compact districts for the native people living. Harbin's situation is the same. If the Russian part of the city has a pre-designed plan with regular and clear blocks of buildings, the planning system of Fu Jia Dian has a really spontaneous character. Even today we can see these huge contrasts between Fu Jia Dian urban planning and other districts of Harbin.

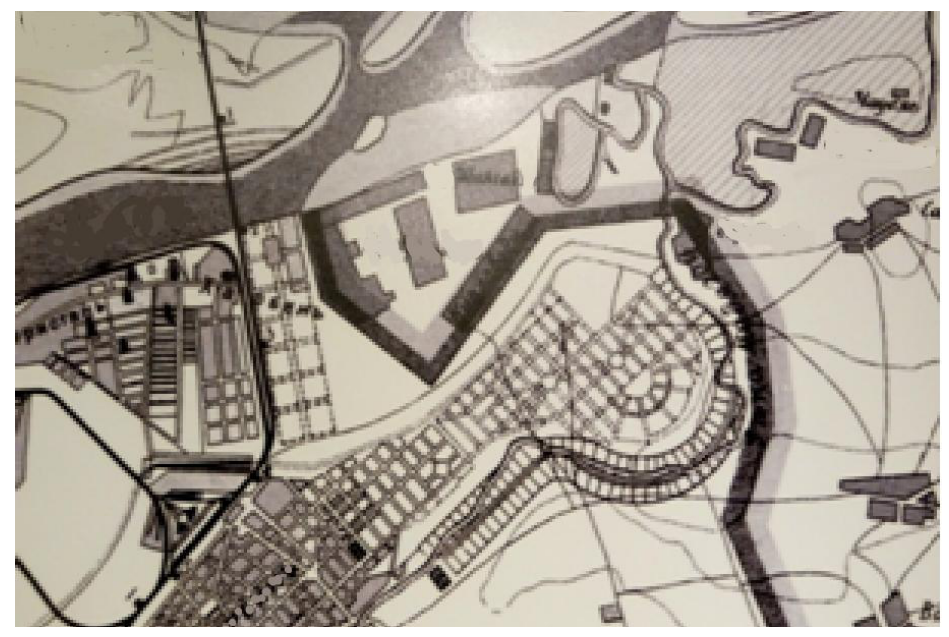

Fig. 1. Urban plan of Harbin on 1902 year. 
At first sight chaotic view of Fu Jia Dian urban planning system, actually, had a traditional way of urban planning organization, where buildings and placed in them function (inside and outside) are closely related with each other. As a result, a lot of niches and recesses appear in the front of buildings intended for the trade and other services. And thin narrow lanes connected the main spaces of district area.

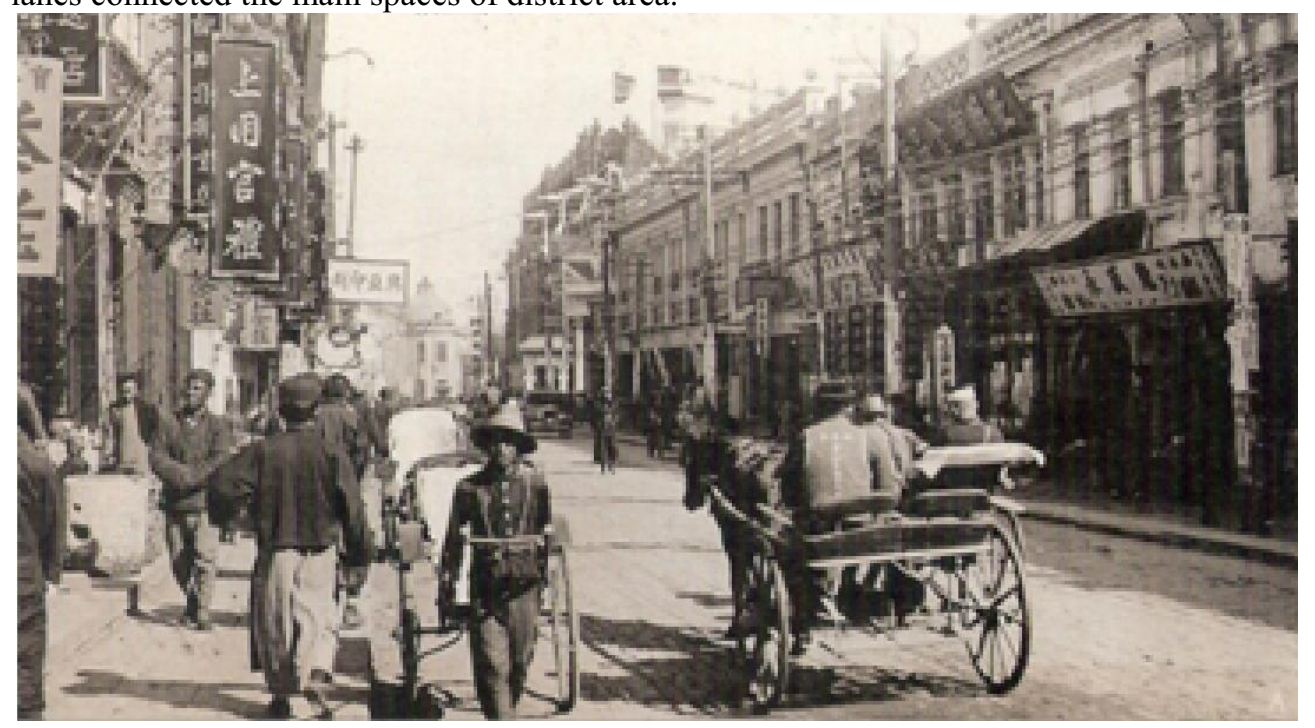

Fig.2. Historic view of Fu Jia Dian (historic photo).

This kind of urban planning design was not comfortable for the automobile transport, but, however, as everybody knows, the rickshaws represented the main transport of China in the early of XXth century, for which narrow and curved streets of Fu Jia Dian were not a barrier. Moreover, the streets being free from the traffic provided the close communication space for the residents: there were held a celebrations, children games, etc. The loss of the former purpose of the streets is the biggest problems of contemporary cities.

Gradually Chinese settlement became to one of the part of Harbin. Urban planning design schemes of 1946 fixed Fu Jia Dian dividing on two parts — West and East. Fu Jia Dian gradually were integrated to the Harbin city structure, that reflected to the new name - Dao Wai in 1956. Dao Wai from Chinese means the district "behind the railway", at the same time, other district Dao Li , former Russian name is Pristan, means "inside the railway".

According to the information of the memories desks in Dao Wai district facades, we can try to reestablish the function accessories of many buildings. Here, besides residential buildings were concentrated a huge number of the small and large factories, art galleries, public and commercial organizations, also including specific buildings with the "amoral" function. But the "amoral" behavior of Fu Jia Dian`s facilities didn`t prevent the work of Chinese theatres and cinematography, Chinese fashion industry was highly developed here. Russian writer Mart, W., who researched this district with ethnographic interests in early 1920th, called Fu Jia Dian as "a children of indigenous Harbin" [8]. It`s reasonable to note, that in spite of hundred years of district development, function of many buildings were saved, there are Christian Church, Synagogue, Cinematography, which work even at this day, pharmacy, banks, martial art club, some shops, etc.

Russian contemporaries noted contrasting neighborhood between Chinese "pathetic Fang $\mathrm{Zi"}$ and European order architecture, that contain the huge colorize significant of $\mathrm{Fu}$ Jia Dian architectural environment (perhaps, the word "Fang $\mathrm{Zi}$ " has Chinese etymology, which means 1-3 floor "house"). The photos of 1920th allow to us make sure in it. 
Actually, "the new Chinese city", which located behind the East-Chinese railway, had completely exotic view, which polar to "Russian imagination of Harbin" with his factories, street advertisement, trade, rickshaws and native people. The unique cultural landscape was created exactly here. In architectural attitude, the most significant point of this landscape was a combination of European architecture and the East highly developed decorative tradition. According to Mi Da Wei historian researcher, Dao Li and Dao Wai districts like a "two different worlds"[1].

\section{The "Chinese -Baroque"origins style and features}

The new artistic phenomenon was born in Fu Jia Dian in 1920th, received the name in Chinese art history of 2000th "Chinese Baroque" — Local Interpretation of Europe Neoclassic. Chinese researches of architecture history called "Chinese Baroque" as a "successful combination of Chinese culturogical conception with house modeling and decorative tradition which include architectural systems and buildings technologies of the West" [9]. At this time, they note, that this style at first may be identify by saturated and sophisticated decoration of the front facades in National-Chinese color $[5,10]$.
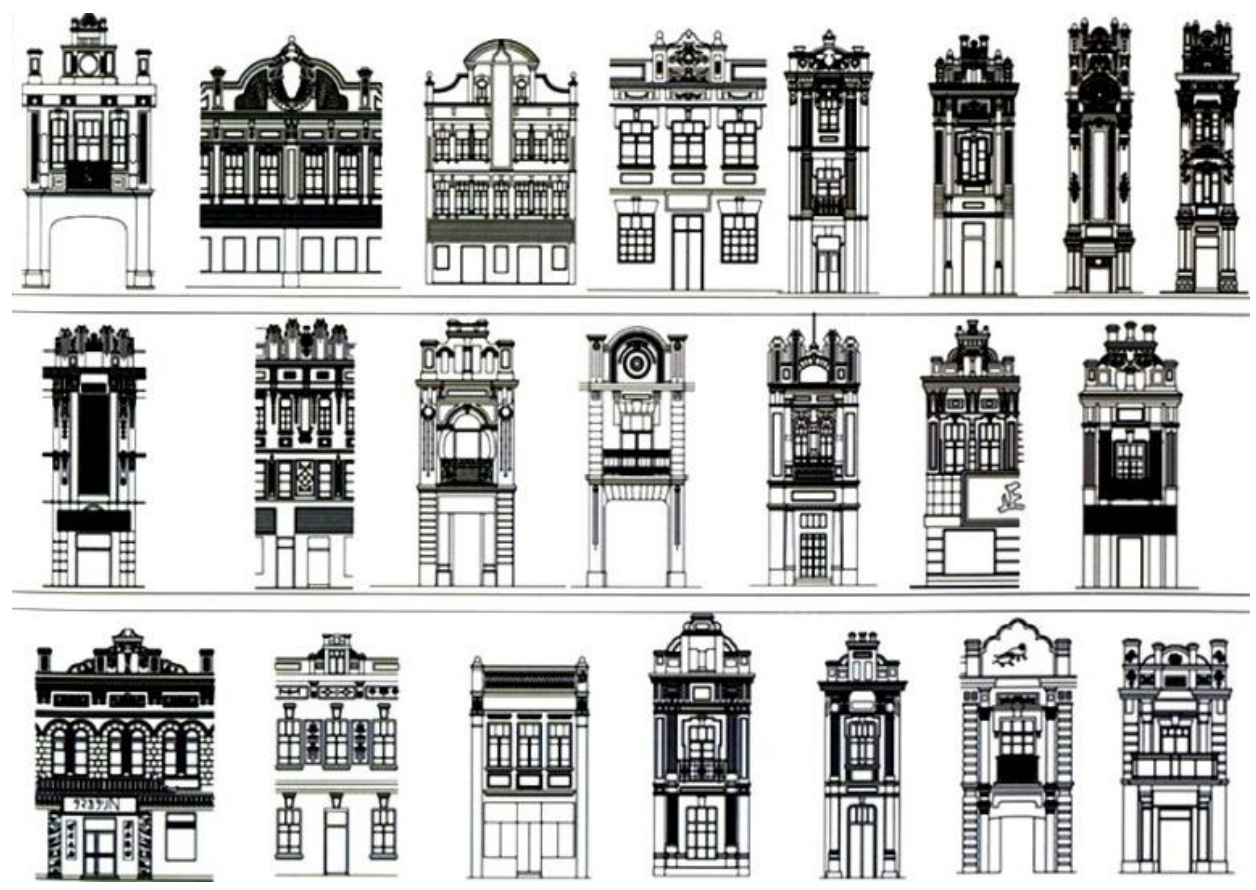

Fig.3. A combination of architectural styles - Modern, Baroque, Classic with Chinese Traditional style.

Authoritative Chinese art researcher Chang Huai Sheng (former professor of the Architectural School of Harbin Institute of Technology, dean of architectural environment design department ) specifically refers this style to the Russian buildings elements (step attic, parapet balustrade, discrete fronton and other architectural elements) and to the baroque decor, which make a huge source for the different distinctive interpretations. It has a row of some buildings of Russian architects A. A. Miaskovsky and U. P. Jdanov in period of 1921 - 1933 years: The Store "Mazuura and Co", Glouberman Residence on Artilleriyskaya Street, Harbin South Manjouli Railway Association, Japan General 
Consulate, Japan-Manzhouli Club, Post-Telegraph Department and some other buildings [7]. As a hypothesis, "Chinese Baroque" buildings also have an attitude to Japanese specialists, because in 1930th they have a very strong positions in Harbin architectural building market.

"Chinese Baroque" mainly focused on the Jing Yang Street, but as shown by research area, other place facilities in Harbin city were built in this style. For example, the threespan arches, which may be read as the prototype of Paifang (Far East Decorative Triumphal Arch). The arch style forming is symbolize of classical tradition and stylistic sample of Ancient Chinese Architecture.

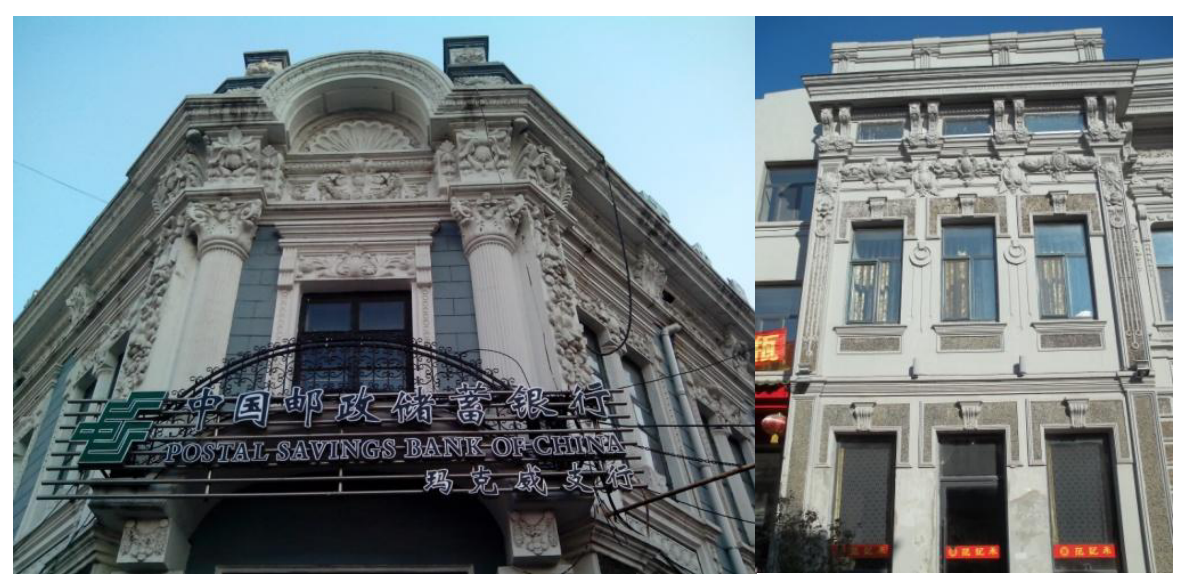

Fig.4. An example of Chinese-Baroque style decoration (renovated part).

\subsection{Dao Way urban environment . For the authorship of buildings and interferences}

Buildings in Fu Jia Dian also were constructed by the European method, specifically by the method of forming quarterly front buildings abutting the firewalls and the facades to each other. Intradomestic confined spaces are typical not only for the income of European homes in XIX-XX centuries, but also for Chinese people tradition, for example, perimeter houses Si He Yuan, that have a garden in courtyard, often met in Ancient Beijing Architecture.

The most significant massive of contemporary Dao Wai with two or three floor buildings consists from the gray bricks buildings structure in rationalistic "brick style", that characterize laconic decoration and other elements of architectural ceramics. 


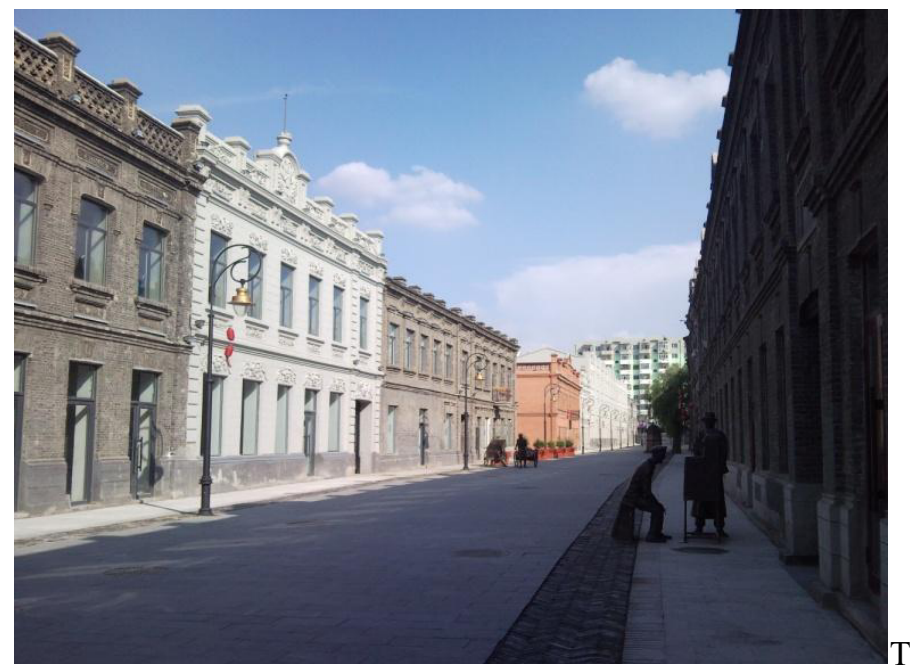

Fig.5. The reconstructed quarter of Dao Wai on 2013.

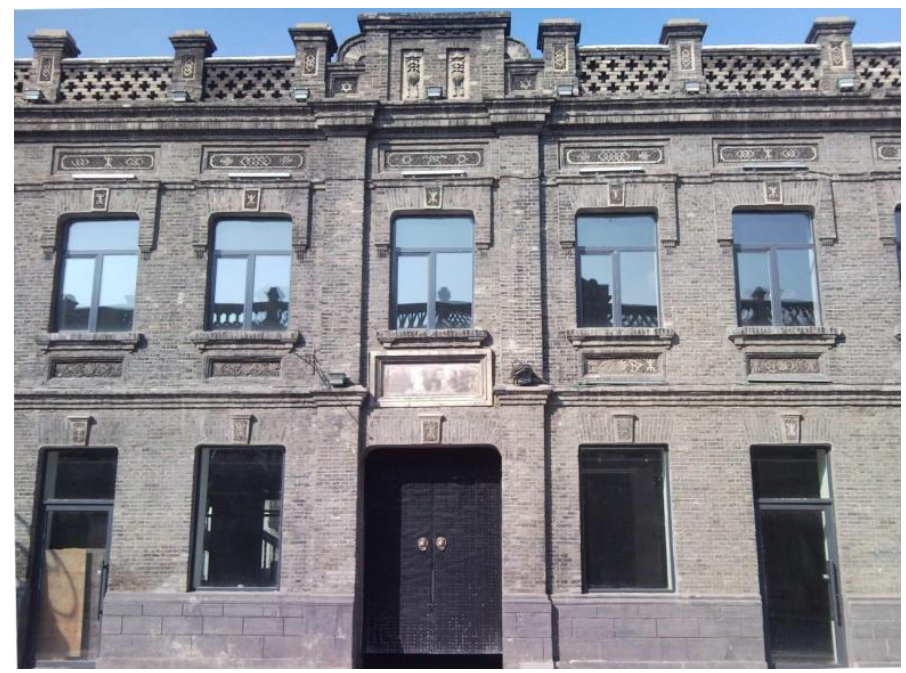

Fig.6. The renovated facade. Rationalistic "brick style".

Remains some open questions, who were the authors of these building projects, these projects exist or not, from which place this experience came here. Chinese researches approved in idea, that the authors were "Chinese masters", "artels". But only one name of Chinese author is possible to know, design architect Zhuang Jun, he was the author of Harbin Communication Ministry Bank in period of 1928-1930 years. Perhaps, Dao Wai reused the Russian author's projects near 1917. There were used the typical project albums of the beginning of 1900th, which also could serve as a basis for self-construction activities. Chinese construction workers have got a huge practical experience on the building sites of Harbin - it is well known Chinese ability to fast "civilize", enterprise and assimilate European life style in all of his forms. The Russian architecture history of Harbin doesn 't have any facts about Russian architects, who works in Fu Jia Dian in 1920th, and even more previously. But since middle of 1930th, when The Buiding Department of Russian Immigrants was founded, regulated by civil engineers brother and sister Ivan Korablev and 
Olga, the huge number of buildings for Fu Jia Dian were designed here (for example, Yi Tond Bank, Muslim mosque, three-floor apartment buildings and other). [11]

\title{
4 Problems of heritage preservation and tourism development
}

\begin{abstract}
Almost for a century there was a significant degradation of Dao Wai. (ill. 8) Chinese researches noted: loss of the many valuable historical and architectural monuments, emergency condition of buildings, increased fire danger, irrational and unreasonable land use, high density of population, failure of the average living space per person, increasing share of non-working population by aging reason, inadequacy using of intradomestic space to the modern requirement, insufficient number of public buildings and open spaces for the rest, unsatisfactory transport infrastructure and functional planning structure of buildings for modern business. Therefore, district space organization and functional planning parameters of several buildings don't satisfy to present requirements. As the result, there are urban environment destruction and economic recession. At this time situation in not renovated North-East part of Dao Wai remains the same - most part of buildings in emergency conditions, without roofs and fire hazard.
\end{abstract}

\subsection{The renovation concept}

The new concept of Dao Wai district renovation project means the transformation of it to one of the three biggest touristic centers of Harbin based on the districts, that were formed in the early period of city in 1900-1930. Two other touristic centers have got Chinese government attention more earlier, therefore they were reconstructed in the end of 1990th. Today this centers are "Architectural Arts Museum of Central Avenue" in Dao Li district (former Pristan) Zhong Yang Street (former Kitaiskaya Street), which opened in 2006 and center in Nan Gang district (The New Town) with dot reconstructed historical buildings, mainly located on Dong Da Zhi street (former Bolshoi Prospect) and Hong Jun street (former Vokzalniy Prospect).

Historical analysis of Dao Wai urban development shows, that many valuable qualities of the historic environment were saved. The authenticity of the buildings has not been lost. There are no high-rise buildings, which has become a real scourge in other areas of historical Harbin. As a consequence, the scale of Dao Wai buildings didn't changed, also valuable views and perspectives, points and ways of perception. Many commercial brands were saved (famous old restaurants, stores, hotels, markets), folklore tradition (advertising, color, form of decoration, holding celebrations). All of these allow to say about integrity of Dao Wai historical environment, it is a key of the cultural landscape value.

\subsection{Gentrification method and its problems}

One of the modern renovation methods of dilapidated historical territory - the gentrification method ("refining" ). What is new in it compared with other types of renovation, redevelopment of the dilapidated industrial and residential environment? The gentrification method has the new urban politics, cultural reassessment of inner city areas and their importance in the city structure. The gentrification method allows reusing urban sources in higher level [12]. A significant rise in cost of real estate and provided services is an inherent consequence of the implementation of this method.

The process of declined districts renovation by using gentrification method is focused on cultural landscape transformation, the real estate cost rising - in this regard on the first 
stage native people migrate to other areas by administrative way. This social moment is the most difficult (the conflict between the new and indigenous people, gradual substitution of the true face by another, oriented to the new needs) and subjected to public critics.

Dao Wai district is the same: the huge housing area of $500,000 \mathrm{~m} 2$ becomes empty from his native people before the realization of renovation reconstruction works. The part of people - was moved to the North-West part of Dao Wai to relatively new seven-floor houses on Jing Yang street, other part - to the outlying north districts of Harbin city Jiang Bei behind the Sungari River. According to Hao Min Qu Development Company the realization of this project inhibits. People don't want to leave their own houses, and as the result, we can see special created troubles with transport system, guards against native people, violent damages of houses and other. The cost of living necessarily will be increased, gentrification initially assumes a higher level of deferred income residents and focused on middle social class. But whether it was formed in Harbin — is the question. So, the social tension is growing up. How it showed by experience, this is negative specific of gentrification method in all of countries.

The concept of Dao Wai Renovation Project means except transformation to the touristic and business center of Harbin. At this day the renovated Dao Wai district remains low populated, many commercial buildings are empty - as a result, it wasn't prepared to full life yet. Therefore it's not the time to make conclusion, because the process of renovation is not full completed yet, and maybe, the social situation problem in Harbin will transform to other forms, than Europe or USA. Russian cities also have partial examples of gentrification method realization, mainly in the biggest cities like Moscow and Saint Petersburg, which also have own specifics.

\section{The implementation of the project. Advantages and disadvantages}

There were reconstructed the huge number of Dao Wai architectural monuments, approved many restoration technologies and the new "Baroque" decoration, renovated big massive of valuable buildings, complex decided public spaces improvement on required level [13-15]. The Dao Wai photographs of 1930s extensive flooding occurred in Harbin.

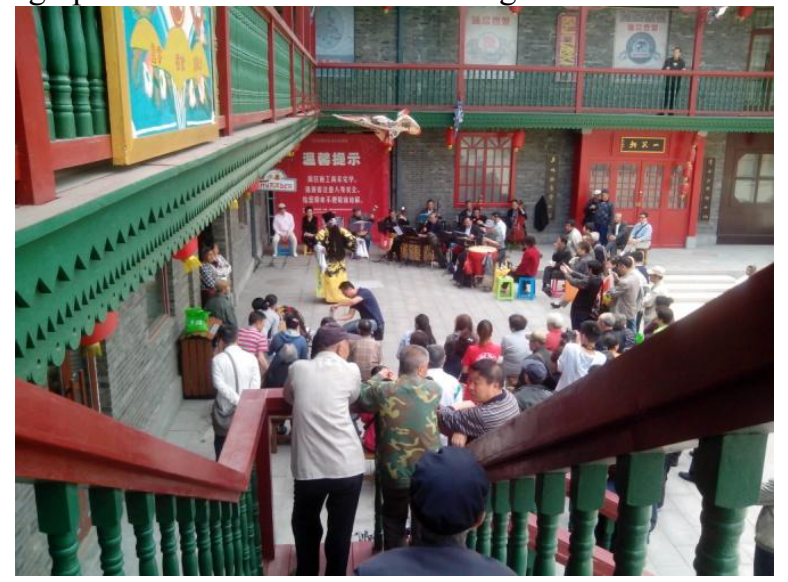

Fig.7. The courtyard as new public space.

There is also new "historicist", metaphorical, symbolic and figurative architecture. For example, main "entrance gate" to the housing area, which may be modeling on the associative level as a Paifang form, designed as sharply stylized three "buildings" facade 
planes. This modern architecture, intellectually and spiritually reached by the new meanings of historical forms, here is appropriate. There were applied covered passages, which connect parallel streets produce the necessary functional and figurative effect in this environmen.

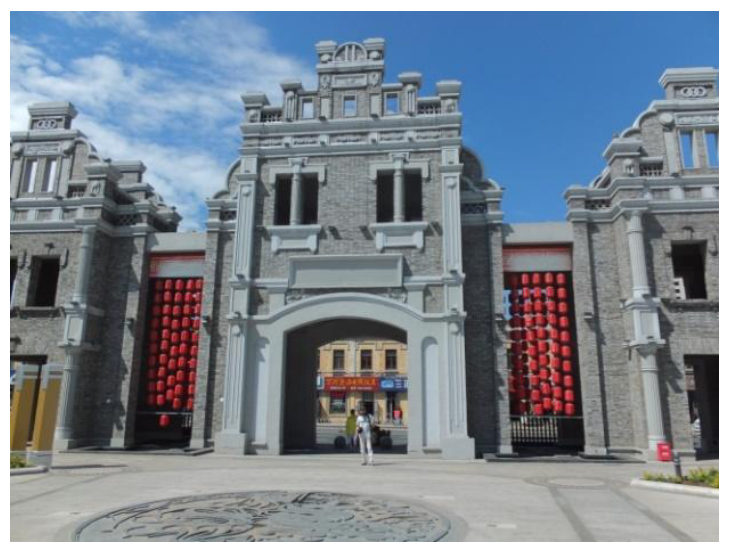

Fig. 8. The old "new methods" of renovation.

There were realized some business facilities projects, strictly subordinated zoning and not exceeding the average height of the historical buildings. Structure of some new buildings is very ultra-modern. For example, Concert Hall on the main square of Dao Wai has unique glass covering structure with span near 30 meters. This building became "the visit card" of this district in line with other architectural monuments.

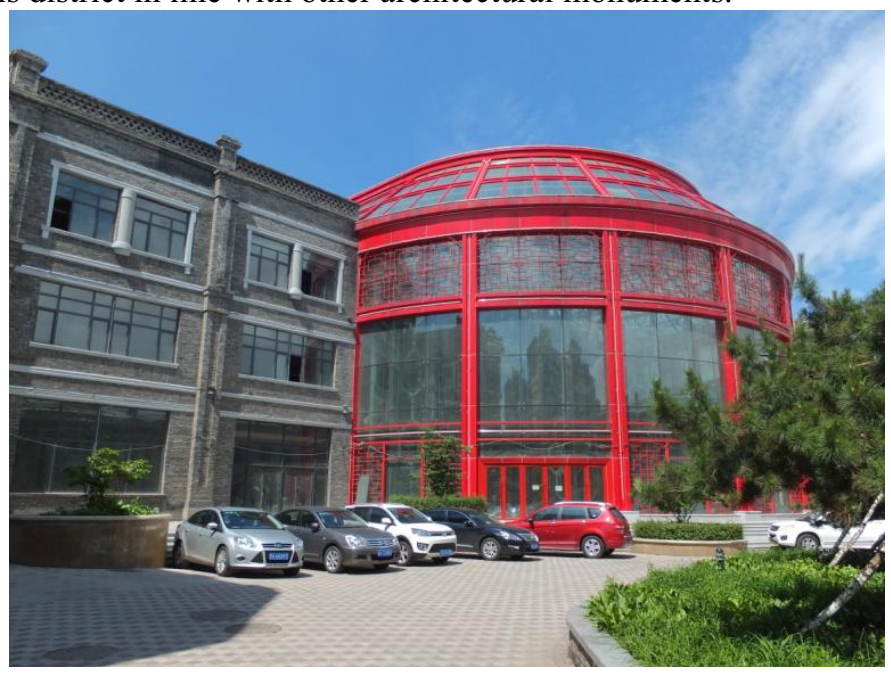

Fig.8. Concert Hall on the main square of Dao Wai.

The principal rejection of the high-rise construction in historical environment of the city is the new word in Harbin urban design politic. Maybe, the negative experience of the urban regulation non-availability in other historical districts is shown the consequences of "the point of no return", for example, Nan Gang district . However, according to observations by several years, the number of high-rise buildings in the historic center of Harbin (especially along the former railway lines) sharply increases. In spite of theatrical effect and "remakes of buildings", "Chinese Baroque" has already achieved originality of local architecture. And in the analyzed region was achieved identity preservation and local architecture personality by the restoration of more valuable buildings, reconstruction inner- 
house spaces, savings of composition specialties, scale and material. Dao Wai district is free from the transport, everything belongs to pedestrian, and this is very powerful factor of his attraction in overpopulated megalopolis.

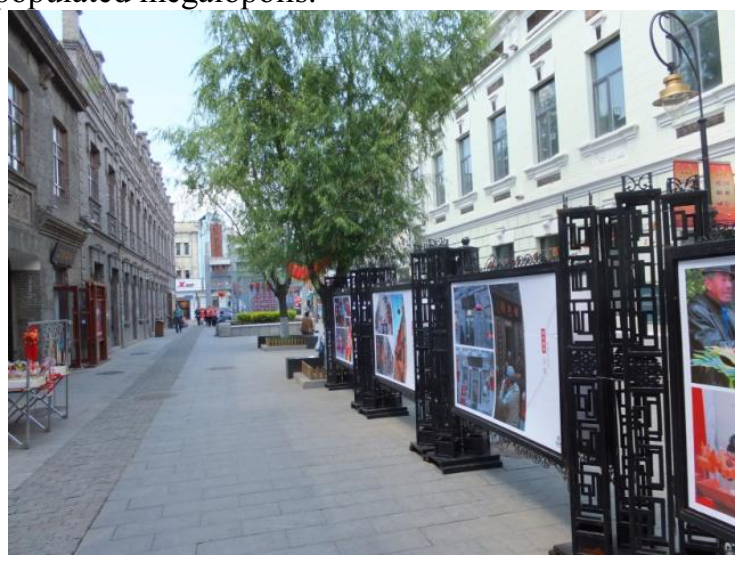

Fig.9. Walking the streets of the renovated Tao Wai.

As shown by location observing area, the project realization in 2015 year has some engineer-technology and exploitation disadvantages: using of low-quality bricks, which have an efflorescence, unsatisfactory setting of rain tubes, leading to the masonry destruction, rented facilities don't cope with his function. Probably, the manufacturing technologies and decoration fixing still not up to par, because in some cases even today we can see destruction. The green spaces are not enough. It seems that the metal sculptures in the renovated part of the Dao Wai are not always in perfect harmony with the urban environment. Also as the disadvantages may be referred the demolition of the large part of Dao Wai construction area, the reason for this demolition was the creation a central square with a fountain surrounded by signs of the zodiac. No one of Harbin architects can give an explanation of the link between historical Dao Wai and zodiac symbols. A significant number of buildings were demolished for the construction of large shopping facilities that surround central square.

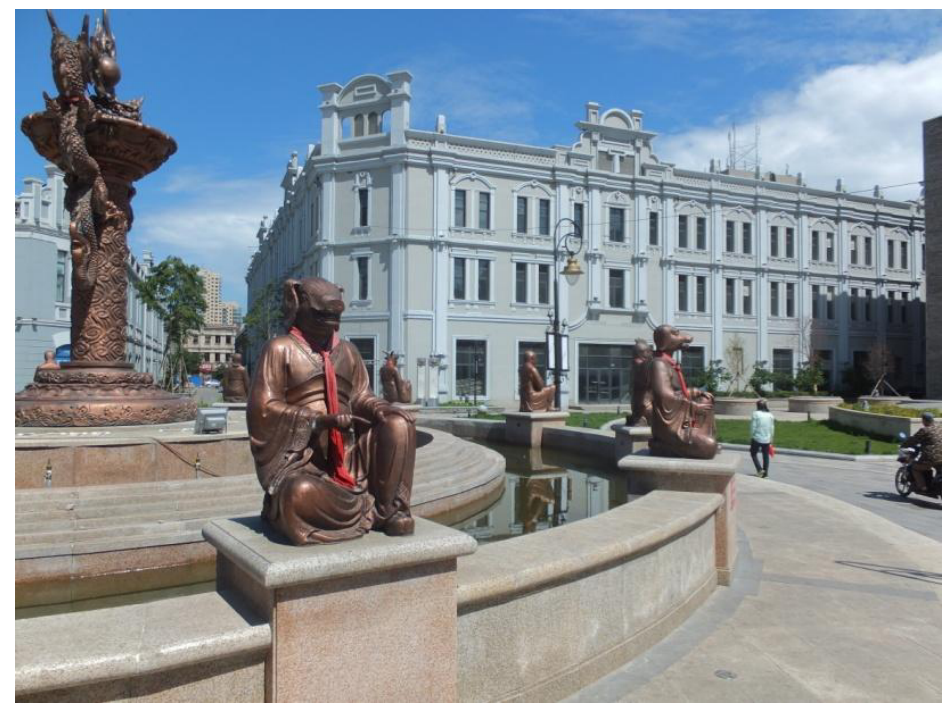

Fig.10. Central square with a fountain in Dao Wai. 


\section{Perspectives of the renovation. New ideas}

Preliminary design of the second phase of the Dao Wai renovation project started in March of 2016 by three architectural design organizations, including Architectural Design and Research Institute of HIT. The new concept of Dao Wai renovation project was based on bigger capital efficiency. The new project was focused on attraction of a larger number of people, by this reason, there is considered a construction of Dao Wai metro station entrance pavilions in the center or on the edge of district in future. The north-western part of Dao Wai is requested to do the most prestigious, with many boutiques, salons, premium restaurants. North-eastern part is requested to focus it on hotel business. The material level of modern residents of Harbin does not allow making a "souvenir streets" for the whole area, because art market in Harbin is not highly developed yet.

In the future, design of Dao Wai does not exclude the possibility of the development of Chinese Baroque. It is important to demonstrate that the Chinese Baroque is not "dead" style from the last century, and it has prospects of stylistic interpretation today and in the future.

Department of Urban Planning in Harbin solves the problem of mass building demolition, appeared in the 1970s-80s (5 - 8 storey residential buildings) surrounding all sides of Dao Wai and significantly reduces the historical and cultural significance of the historic environment. Today, historic district Dao Wai does not have concrete boundaries, just line of construction area. Most likely, the main street of Dao Wai will remain a traffic, and the side streets will be fully provided for pedestrians. Now huge market is situated in the north-western part of Dao Wai, it is possible to relocate this. As an effort to give a breathe for "new life" to the historic district is considered another one method, namely: using of deconstructivist forming for the creation of a new center, it will attract people by analogy with the large-scale renovation project in Shanghai, Shenzhen and Beijing (project of "Gallery Street 798"). According to Harbin architects opinion, Daniel Libeskind's deconstructionist projects demonstrate the effectiveness of this practice - the historic area becomes more interesting not only for architects, but also for ordinary people. Although, population of Harbin, according to recent data, exceeded 12 million people, Harbin continues to be referred to the third line of development. The first line includes Shanghai, Shenzhen and other cities. Development lines suggest the appropriate amount of public investment in urban infrastructure. Many modern experts emphasize the impossibility of the development of modern cities without relying on a rich historical past, which, in particular, has Harbin.

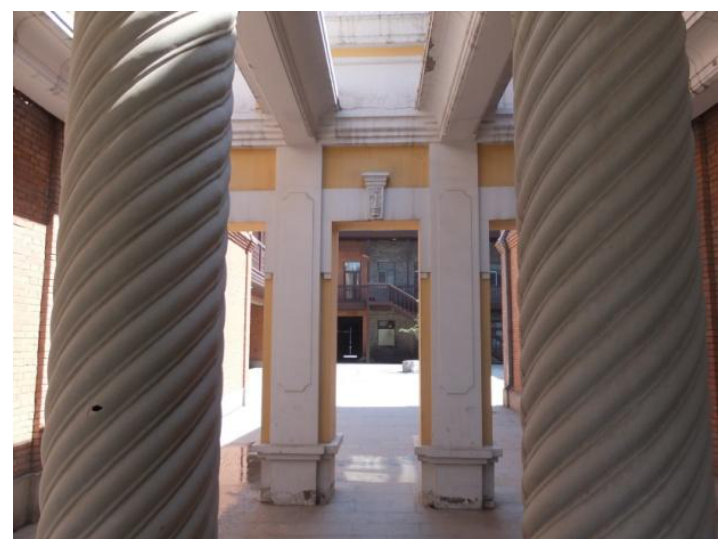

Fig.11. Renovated communication infrastructure. 


\section{Conclusion}

This article does not consider the economic efficiency questions. However without doubt, business development, good furnished local zones systems for the rest, trade, entertainment - all of this will grow up touristic attraction of this district Dao Wai and give own urban, ecological and economical effect. From the unique architectural environment point, Dao Wai - is the worthy concurrent to other tourist centers in Harbin, making his stake on European architecture and unique culture from the Russian background. It seems, that "Chinese Baroque" district may take the focus not only for domestic tourists in future, but also may attract foreign people. The realization project, how it was remarked, on the finish stage, but even today this place makes an impressiveness by his complex approach, saturation of functional and aesthetic content of each environment fragment. There are increasing of social function and the status of Dao Wai as a part of urban space. The Dao Wai renovation project gives us the model, which may be analyzed and adapted to different countries.

\section{References}

1. M. D. Wei, D. B. L. Shi, Hei - Ji - Liao Ji Dong Mang Tong Lan, 240 (Heilongjiang Publish Society Harbin, 2014).

2. W. Ting, R.Lifen, T. Wei, Hua Zhong Architecture, 3, 128-132 (2011)

3. M. Huanwei, J.Li, Shanxi Architecture, 1, 46-47 (2010)

4. A.P.Ivanova, H. P. Kradin, Vestnik TOGU, 4(35), 31-40 (2014)

5. W. Yang. L.Daping, L. Tong, Architectural History, 11, 185-187 (2006)

6. Information on: http://news.my399.com/zt/content/2014-12/23/content_1400474.htm

7. C. H. Sheng, The Art of Architecture in Harbin (Harbin, 1989).

8. S.A. Zabiyako, A. P. Zabiyako, S. S. Levoshko, A. A. Hisamutdinow, Russkiy Harbin: opit zhiznestroitel'stva $v$ usloviykh dal'nevostochnogo frontira (AmGU, Blagoveshchensk, 2015).

9. Sino-Russian forum at the highest level on the theme of architectural styles and city design. Conference materials, 18 ( Harbin, 2006).

10. C. X. Zhen, Guangdong province Architectural Design Institute, 4, 153-156 (2010)

11. N.P. Kradin, Harbin - Russkay Atlantida: ocherki (Khabarovsk, 2010)

12. G. A. Ptichnikova, Sovremennay arkhitectira mira, 3, 177-190 (2013)

13. L. X. Bo, Architectural Design and Research Institute of HIT, Harbin, 8, 38-40 (2012)

14. L. C. Lai, Q. L.Yan, L.B. De, Sichuan Building Science, 8, 111-113 (2011)

15. J. Hong, S.Yan, Shanxi Architecture, 4, 12-15 (2010) 